\title{
Description Of Hospitalization Stress Of Children's Age Pre-School
}

\author{
Asnidar $^{*}$, Haerati ${ }^{2}$,Hilmi Nurfadillah ${ }^{3}$ \\ Departemen of Child And Maternity Nursing, Stikes Panrita Husada Bulukumba, Indonesia ${ }^{2}$ \\ Departemen Community and Family Nursing , Stikes Panrita Husada Bulukumba ,Indonesia ${ }^{3}$ \\ S1 Nursing Study Program, Stikes Panrita Husada Bulukumba, Indonesia ${ }^{1}$
}

Corresponding Autor: Asnidarnidar16@yahoo.co.id*

\begin{abstract}
Preschool children are children who are vulnerable to stress because the child's ability to treat stress is still limited where hospitals can be stressful for children, so children will increase the stress of hospitalization. Hospitals can be adjusted by several factors, one of which is caring for nurses. The purpose of this study was to study the stress level of pre-school age children's hospitals in the Mawar Room and Pavilion of H.Andi Sulthan Daeng Radja Hospital in Bulukumba Regency.The research design used was a descriptive survey with a total sample of 30 respondents. The results showed that changing the stress of hospitalization was predominantly male by 20 respondents (66.7\%), children who had never been hospitalized as many as 25 respondents (83.3\%) and the majority of children who experienced stress hospitalization were 18 respondents (60\%). From the research it can be concluded that hospital stress can be carried out on all boys and girls, both children who are hospitalized for the first time or who have been repeatedly hospitalized, so that it is recommended to the organizations concerned to improve service especially in discussions at the pavilion's nursing home. and roses by creating a pleasant atmosphere, making room arrangements that can reduce stress in children who are cared for care.
\end{abstract}

Keywords: Hospital, Stress Levels

\section{INTRODUCTION}

Children are part of the family and community. Children who are sick can cause stress for the child itself and family (Setiawan et al, 2014 in Kaluas, et al, 2015). In the United States, it is estimated that more than 5 million children undergo hospitalization due to surgical procedures and more than $50 \%$ of that amount, children experience anxiety and stress. It is also estimated that more than 1.6 million children and children between 2-6 years of age undergo hospitalization due to injuries and various other causes (Disease Control, National Hospital Discharge Survey (NHDS) (Kaluas, et al, 2015).

The morbidity rate of children in Indonesia based on the 2013 National Health Survey (Susenas) cited by Kaluas, et al, 2015 in urban areas according to the age group $0-4$ years by $25.8 \%$, ages $5-12$ years as much as $14.91 \%$, age $13-15$ years around $9.1 \%$, if calculated from the total population is $14.44 \%$. Children who are hospitalized will affect 


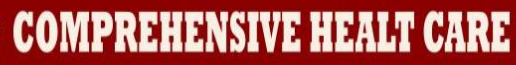

the physical and psychological condition, this is called hospitalization (Kaluas, et al, 2015).

In South Sulawesi Province the number of visits of pediatric patients to inpatients in hospitals in each region was $20.49 \%$ (2011) then decreased to 14\% (2012) and tended to remain in 2013 which was 14, 65\% and again in 2011 to 14, 53\%. Data on the incidence of stress hospitalization in children at the Wahidin Sudirohusodo General Hospital in Makassar shows that from October to December 2016 there are approximately 417 children admitted to children in class II. And those treated in class III are around 3065 children and most children experience stress hospitalization on the first day of treatment or about 67\% (Hudriyah et al. 2016).

Meanwhile, data obtained from the Pavilion and Mawar treatment rooms from October to December 2016 recorded 159 children undergoing treatment and 140 children experienced stress hospitalization on the first-second day of treatment. (Data on Pavillion and Mawar Room of H. Andi Hospital. Sulthan Daeng Radja Bulukumba, 2016). Children who experience illness and undergo treatment in the hospital will be forced to separate from the environment that they feel safe, loving, and fun, namely home, games, and friends with the game. this process is said to be the process of hospitalization. Hospitalization is a process, which for some reason is either an emergency or plans to require the child to stay in the hospital undergoing therapy and treatment until returning home (Suryanti, 2013 in Tae, et al. 2014).

Sickness and hospitalization are the main crises seen in children. If a child is hospitalized, the child will be prone to crisis because the child experiences stress due to changes in both his health status and the child's environment in daily habits, has several limitations in coping mechanisms to deal with problems or events that are pressing. various feelings that often arise in children, namely anger, sadness, fear, and guilt. Hospitalization in pediatric patients can cause stress at all age levels. The cause of stress is influenced by many factors, both from the officers (nurses, doctors, and other medical personnel), the new environment, and the family that accompanies it (Eni, 2010). Prestudy results through observation are known that almost all children are accompanied by their parents during treatment in hospital and many children cry and refuse when treated (Eni, 2010).

Nurses are one of the professions in hospitals that play an important role in the implementation of efforts to maintain the quality of health services in hospitals. The 


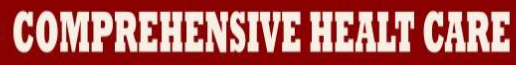

important role of a child nurse, namely as a defender (advocacy), educators, counselors, ethical decision-makers, health planners, coaches therapeutic relationships, monitors, evaluators, and researchers. Nurses as advocates are required to be advocates for children/families when they need help, cannot make decisions / make choices, and convince families to be aware of the services available, treatment, and procedures carried out by involving the family (Puspita, 2013).

A preliminary study conducted by researchers through interviews with the head of the room in the Rose treatment room (child care) and pavilion, found that $80 \%$ of preschool-age children who were first admitted to hospital refused to get medical treatment by home health workers sick. Children are also frightened and cry when nurses enter the room where they are treated while carrying medical equipment and also refuse to be invited to cooperate in conducting treatment procedures. Also from observations, some children refuse when children will be assisted by nurses' needs, usually, those who meet the needs of children are parents who accompany the child at that time. And the data obtained that the number of pediatric patients entered in the care of roses and pavilions from January to February 2017 as many as 69 children. Where children undergo hospitalization in the care of roses and the Pavilion of RSUD H. Andi Sulthan Daeng Radja Bulukumba, more than $80 \%$ are attended by their parents. And it was found that $80 \%$ of preschool-aged children who were treated experienced anxiety characterized by an increase in pulse frequency, increased blood pressure, increased breathing frequency, diaphoresis, trembling, palpitations, nausea, and vomiting.

Preschool children are children who are prone to stress because the child's ability to treat stress is still limited where the condition of hospitalization can be stressful for children so that children will experience stress hospitalization. Stress hospitalization in children can be influenced by several factors.

From this background, the authors are interested in conducting research on the description of the level of stress hospitalization in preschool children in the Mawar Room and the Pavilion of H. Andi Sulthan Daeng Radja Bulukumba.

\section{MATERIAL AND METHODS}

This type of research in this study is a descriptive survey with a quantitative approach where this study aims not to search for or explain relationships, not test hypotheses or make predictions (Saryono, 2013). Population is a generalization area consisting of objects, subjects that have certain quantities and characteristics 


\section{COMPREABENSWE HEAM GARE}

determined by researchers to be studied and then conclusions are drawn (Saryono, 2013). The population in this study were all preschool children who were treated in Pavillion and Rose care as many as 69 people.

The sample in this study amounted to 30 pre-school children this is following the theory put forward by Gay and Diehl (1992) in Sayono. 2013 believes that the sample must be as large as possible. The opinion of Gay and Diehl (1992) assumes that the more samples taken, the more representative and the results can be adjusted. But the sample size received will depend on the type of research. If the research is correlational, the minimum sample is 30 subjects.

The research instrument used to collect data is primary data sourced from questionnaires. The questionnaire method is a method of collecting data by providing a list of statements. A written statement with several choices of answers to the respondent (Saryono. 2013). The research instrument used was a questionnaire sheet about the stress of Hospitalization in pre-school age children.

\section{RESULTS}

Table 1. Distribution of Respondents by Age, Gender, Educational Level and Occupation

\begin{tabular}{lcc}
\hline Age & n & Persentage (\%) \\
\hline Late teens & 9 & 30,0 \\
Early adulthood & 14 & 46,7 \\
Late adulthood & 5 & 16,7 \\
Early Elderly & 2 & 6,6 \\
Gender & & \\
Male & 9 & 30,0 \\
Female & 21 & 70,0 \\
Level Of Education & & 33,3 \\
Basic & 10 & 43,3 \\
Middle & 13 & 23,4 \\
Hight & 7 & 26,7 \\
Proffesion & & 50,0 \\
Housewife & 8 & 13,3 \\
Enterprenership & 15 & 10,0 \\
Civil Servant & 4 & 100 \\
Farmer & 3 & $\mathbf{1 0}$ \\
\hline Amount & $\mathbf{3 0}$ & . \\
\hline
\end{tabular}

Table 1 shows that based on the age characteristics of the child's parents or guardians most of the children included in the early adult age group were 14 respondents (46.7\%), late teens were 9 respondents (30.0\%), Late Adults were 5 respondents $(46,7 \%)$ and the initial elderly were 2 respondents $(6.6 \%)$. Characteristics of respondents based on the sex of parents/guardians were mostly female by 21 respondents (70.0\%) and males by 9 respondents (30.0\%). The education characteristics of most respondents were found in the group of respondents with a 


\section{COMPRABHENSWE HEAH CARE}

secondary education level of 13 respondents (43.3\%), low education of 10 respondents (33.3\% 0 and higher education of 7 respondents (23.4\%). Table 5.4 shows the characteristics most parents/guardians based on work found parents who worked as entrepreneurs as many as 15 respondents (50.0\%), IRT as 8 respondents (26.7\%), civil servants as many as 4 people (13.3\%) and farmers as many as 3 respondents $(10.0 \%)$.

Table 2. Distribution of Respondents by Gender of Children and Hospitalization History

\begin{tabular}{lcc}
\hline Gender & n & Persentage (\%) \\
\hline Male & 20 & 66,7 \\
Female & 10 & 33,3 \\
History of Hospitalization & 5 & 16,7 \\
Yes & 5 & 83,3 \\
No & 25 & $\mathbf{1 0 0}$ \\
\hline Amount & $\mathbf{3 0}$ & \\
\hline
\end{tabular}

Table 2 . shows that the characteristics of children by sex are mostly male with 20 respondents (66.7\%) and women with 10 respondents (33.3\%). Based on the history of hospitalization, there were 25 children (83.3\%) who had never been hospitalized before and 5 respondents (16.7\%) were hospitalized.

Table 3 Distribution of Respondents by Stress Hospitality for Preschoolers

\begin{tabular}{lcc}
\hline Stress Hospitalization & n & Persentage (\%) \\
\hline Stress & 18 & 60,0 \\
Not Stress & 12 & 40,0 \\
\hline Amount & $\mathbf{3 0}$ & $\mathbf{1 0 0}$ \\
\hline
\end{tabular}

Table 3. shows that the majority of children who experienced stress hospitalization were 18 respondents (60\%) and those without stress hospitalization were 12 respondents (40\%).

\section{DISCUSSION}

The results showed that the majority of children who experienced stress hospitalization were 18 respondents (60\%) and those who did not experience stress hospitalization were 12 respondents (40\%). In this study, it was still found that children who experienced hospitalization stress naturally happened, because when treated the child tended to feel his freedom to play lost, the child felt watched and the child felt uncomfortable in the hospital environment. In this case, it takes time for the child to adapt to the environment in which he is being treated.

The results of this study are in line with research conducted by Jannah (2016) were from the results obtained that stress levels in children categorized as moderate stress have a large percentage of 14 children (73.7\%). Based on gender, girls have the largest proportion in the moderate stress category, as many as 9 children (64.3\%). Children 


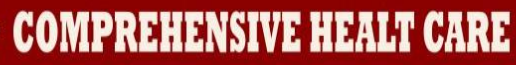

aged 11-12 years have a large percentage with the category of moderate stress as many as 8 children (57.1). And children who have previous hospitalization experience have a large percentage in the category of moderate stress that is equal to 10 children $(71.4 \%)$. According to hospitalization is a state of crisis in children, when the child is sick and hospitalized. Hospital is a process due to planning or emergency reasons that require children to stay in the hospital to undergo therapy and treatment. Even so, being hospitalized is still a big problem and causes fear, anxiety, for children. Hospitality can also be interpreted as some psychological changes that can be the cause of children being hospitalized (Supartini, 2011).

Based on this understanding, it can be concluded that hospitalization is a process due to both planning and emergency reasons that require the child to be treated or stay in the hospital to get the treatment that can cause some psychological changes in the child. From the results of this study, it can be assumed that the majority of pre-schoolaged children treated in hospitals or in other health services experience stress hospitalization. Child stress during hospitalization occurs because of a stressor. This is because children experience separation from parents and peers, loss of control or control, bodily injury and pain, and fear of pain itself. Stress due to hospitalization in pre-school age children is an individual's response to situations that cause pressure, change, adjusting demands, giving caregivers unknown and losing independence, feeling uncomfortable with the state of the environment.

\section{CONCLUSIONS}

Based on the results of data analysis and discussion in the previous chapter, the conclusion of this study is the level of stress hospitalization for most children who experience stress hospitalization as many as 18 respondents (60\%) and who do not experience stress hospitalization as many as 12 respondents (40\%). Improving services, especially in handling stress hospitalization in pre-school age children in the pavilion and rose care rooms by creating a pleasant atmosphere, making a cheerful room setting to reduce anxiety in children undergoing treatment. 


\section{REFERENCES}

Cut. 2012. Gambaran tingkat stres pada anak usia sekolah selama hospitalisasi di Rumah

Sakit Anak dan Bunda Harapan Kita Jakarta, tahun 2012. http://repository.uinjkt.ac.id/dspace/h andle/123456789/1347 diakses tanggal 4 Oktober 2017.

Data Kepegawaian RSUD H. A. Sulthan Daeng Radja Bulukumba. 2017

Eni. 2010. Perkembangan Anak. EGC. Jakarta.

Hudriyah, dkk. 2016. Hubungan Dukungan Keluarga Dan Lingkungan Rumah Sakit Dengan Reaksi Hospitalisasi Pada Anak Usia PraSekolah Di RSUP Dr. Wahiddin Sudirohusodo Makassar

Jannah. 2016. Gambaran Tingkat Stres Pada Anak Usia Sekolah Dengan Hospitalisasi Ri RSUD Labuang Baji. Universitas Islam Negeri Alauddin Makassar.http://repositori.uinalauddin.ac.id/1576/1/NUR\%20IFDATUL\%20JANN AH.pdf. dikases tanggal 4 Oktober 2017.

Kaluas, dkk. 2015. Perbedaan Terapi Bermain Puzzle Dan Bercerita Terhadap Kecemasan Anak Usia Prasekolah (3-5 Tahun) Selama Hospitalisasi Di Ruang Anak Rs Tk.III.R. W. Mongisidi Manado.

Natalia. R. 2014. Hubungan Perilaku Caring Perawat Dengan Tingkat Kecemasan Anak Usia Sekolah Yang Dirawat Di Ruang Perawatan Anak Di Rsud Panembahan Senopati Bantul.

Nursalam, Susilaningrum, R, \& Utami, S. 2011. Asuhan Keperawatan Bayi Dan Anak (Cetakan Ke II). Salemba Medika. Jakarta.

Maryunani. 2010. Ilmu Kesehatan Anak Dalam Kebidanan. TIM. Jakarta.

Puspita. 2013. Hubungan Tingkat Pengetahuan Perawat Dengan Perilaku Perawat Dalam Meminimalkan Kecemasan Akibat Hospitalisasi Pada Anak Prasekolah Di RSUD Dr. Moewardi. S1 Keperawatan Fakultas Ilmu Kesehatan Universitas Muhammadiyah Surakarta 2013.

Supartini, Yupi. 2011. Buku Ajar Konsep Dasar Keperawatan Anak. EGC. Jakarta.

Tae, Fransiskus, dkk. 2014.Partisipasi Orang Tua Dalam Meminimalkan Stres Hospitalisasi Pada Anak Usia Pra Sekolah. STIKES RS. Baptis Kediri Jl. Mayjend Panjaitan No. 3B Kediri 64102

Utami, Yili. 2015. Dampak Hospitalisasi Terhadap Perkembangan Anak. Sekolah Tinggi Ilmu Kesehatan Binawan. 